Hans van Loon, ${ }^{*}$

Former Secretary General of the Hague Conference

on Private International Law (1996-2013)

Member of the Institut de Droit International
ОРИГИНАЛНИ НАУЧНИ РАД

doi:10.5937/ zrpfni1982015L

UDK: 341.24

341.9

Рад примљен: 18.02.2019.

Рад прихваћен: 13.04.2019.

\title{
TOWARDS A GLOBAL HAGUE CONVENTION ON THE RECOGNITION AND ENFORCEMENT OF JUDGMENTS IN CIVIL OR COMMERCIAL MATTERS ${ }^{* *}$
}

\section{Introduction}

1. The Government of the Netherlands has convoked a Diplomatic Session of the Hague Conference on Private International Law to be held from 18 June to 2 July 2019 at the Peace Palace in the Hague. Its purpose will be to adopt a Convention on the Recognition and Enforcement of Foreign Judgments in Civil or Commercial Matters. In order to prepare the Session, a Special Commission of the Hague Conference has drawn up a Draft Convention (the "2018 Draft"). ${ }^{1}$ This Draft, adopted in May 2018 in English and French, is accompanied by an Explanatory Report by Prof. Francisco Garcimartín and Prof. Geneviève Saumier, ${ }^{2}$ who took part in the Special Commission as experts of Spain and Canada, respectively.

2. In addition to the preparation of the Diplomatic Session, arrangements are underway for a further meeting of an Experts' Group to address "matters relating to direct jurisdiction (including exorbitant grounds and lis pendens/declining jurisdiction), to be held shortly after the conclusion of the Diplomatic Session". ${ }^{3}$

\footnotetext{
*hans.vanloon@ppl.nl

${ }^{* *}$ This paper reproduces the text of a lecture given by the author at the Faculty of Law University of Niš (Center for Private International Law of the Hague Conventions) on the 10th of April 2017.

1 See the Draft Convention on the Recognition and Enforcement of Foreign Judgments in Civil or Commercial Matters, Retrieved 1 February 2019, from https://assets.hcch.net/ docs/9faf15e1-9c36-4e57-8d56-12a7d895faac.pdf . The 2018 Draft Convention's text is available in this Journal at page 307.

2 Prel. Doc. No 1 of December 2018 - Judgments Convention: Revised Draft Explanatory Report, Retrieved 01, February 2019, from https://assets.hcch.net/docs/7d2ae3f7-e8c64ef3-807c-15f112aa483d.pdf.

3 Council on General Affairs and Policy of the Hague Conference on Pivate International Law, Conclusions and Recommendations, March 2018, Retrieved 1 February 2019, from https://
} 
3. The current project started with a proposal submitted by the United States of America in 1992, which first led to an attempt to negotiate a "mixed" convention. The idea, developed by Prof. Arthur von Mehren, was to draw up an instrument that would: (1) permit certain grounds of jurisdiction (the "white" or "green" list), judgments based upon which must be recognized and enforced by all Contracting States, (2) prohibit certain grounds of jurisdiction (the "black" or "red" list), judgments based upon which may not be recognized and enforced, and (3) leave a "grey area" of grounds of jurisdiction to national law, judgments based upon which Contracting States remain free to recognize and enforce, or not (von Mehren, 2002: 408-425 with further references).

4. With the "mixed" convention concept as a start, negotiations took place from 1996 until 2001. But the resulting 2001 Interim Text, ${ }^{4}$ preceded by a Preliminary Draft Convention in 1999, ${ }^{5}$ left many issues unresolved and was not followed by a final text. Therefore, it was decided to take a step back and focus, first, on a possible instrument on jurisdiction and recognition and enforcement of foreign judgments only in cases where commercial parties conclude an exclusive choice of court agreement. This led to the adoption, on 30 June 2005, of the Hague Convention on Choice of Court Agreements ("COCC"), ${ }^{6}$ which entered into force on 1 October 2015.

5. Following the completion of the COCC in 2005, a new attempt was made to negotiate a Convention with a wider substantive scope. Without abandoning the idea of an instrument dealing both with the issue of original ("direct") jurisdiction of the courts - a traité double, negotiations have been concentrated on an instrument on recognition and enforcement of judgments only - a traité simple. This has resulted in the 2018 Draft, as the basis for the 2019 Diplomatic Session.

\section{Background and Context}

6. The work of the Hague Conference on judgments in civil and commercial matters has a long history (Teitz, 2019). Since the 1960's, this history has been intertwined with legislative action regarding civil and commercial judgments

www.hcch.net/en/governance/council-on-general-affairs> Archive> Meeting 2018.

4 Permanent Bureau and the Co-reporters, Summary of the Outcome of the Discussion in Commission II of the First Part of the Diplomatic Conference 6 - 20 June 2001, Interim Text, Retrieved 01, February 2019, from https://assets.hcch.net/docs/e172ab52-e2de-4e40-905111aee7c7be67.pdf.

5 Preliminary Draft Convention on Jurisdiction and Foreign Judgments in Civil and Commercial Matters, Retrieved 01, February 2019, from https://assets.hcch.net/docs/638883f3-0c0a46c6-b646-7a099d9bd95e.pdf.

6 Convention of 30 June 2005 on Choice of Court Agreements. 
in the context of the European Economic Community (EEC), subsequently the European Union (EU).

\subsection{The 1965 Choice of Court and 1971 Recognition and Enforcement Conventions}

\subsubsection{Interaction with the 1968 Brussels Convention}

7. The first Hague attempts to draw up a multilateral treaty on recognition and enforcement of judgments date back to the 1920's. They were resumed after the Second World War. In 1956, a Convention on Choice of Court Agreements in the Context of International Sales Contracts saw the light, and was first signed in $1958 .^{7}$ This instrument, in turn, inspired a Convention on the Choice of Court ${ }^{8}$ with a wider scope, adopted in 1964 and first signed in 1965. But neither of these instruments entered into force.

8. In 1966, the Conference adopted a Convention on the Recognition and Enforcement of Foreign Judgments in Civil and Commercial Matters, ${ }^{9}$ first signed in 1971. But this instrument made the recognition and enforcement subject to a bilateral agreement to be concluded between any two Contracting States to the Convention. In addition, the Convention was supplemented by an optional Protocol ${ }^{10}$ that excluded a number of "exorbitant" grounds of jurisdiction.

9. The 1958, 1965 and 1971, the Hague Conventions ${ }^{11}$ provided inspiration for the work of the Member States of the EEC that resulted in the 1968 Brussels Convention on the Jurisdiction of the Court and Recognition and Enforcement of Judgments in Civil and Commercial Matters. But the Brussels Convention, now the Brussels Regulation 1215/2012 (Recast) ${ }^{12}$ ("Brussels I recast"), went much

7 Convention of 15 April 1958 on the jurisdiction of the selected forum in the case of international sales of goods.

8 Convention of 25 November 1965 on the Choice of Court.

9 Convention of 1 February 1971 on the Recognition and Enforcement of Foreign Judgments in Civil and Commercial Matters. See Fragistas, 1969: 360-388.

10 Supplementary Protocol of 1 February 1971 to the Hague Convention on the Recognition and Enforcement of Foreign Judgments in Civil and Commercial Matters. See Droz, 1969: 498-504.

11 As well as the Convention of 15 April 1958 concerning the recognition and enforcement of decisions relating to maintenance obligations towards children.

121968 Brussels Convention on jurisdiction and the enforcement of judgments in civil and commercial matters, OJ L 299, 31.12.1972, as modified by Council Regulation (EC) No 44/2001 of 22 December 2000 on jurisdiction and the recognition and enforcement of judgments in civil and commercial matters, OJ L 12, 16.1.2001 and Regulation (EU) No 1215/2012 
further than the Hague texts in major respects. It (1) includes uniform rules on direct jurisdiction - going beyond the original objective of establishing uniform rules for the recognition and enforcement of judgments only, (2) provides for recognition and enforcement generally without review of the grounds of jurisdiction, and (3) benefits from a mechanism of uniform interpretation by the Court of Justice of the EU (CJEU).

10. Soon after its adoption, the Brussels Convention turned out to be a great success. It provided the model for the Lugano Convention of $1988,{ }^{13}$ revised in $2007 .{ }^{14}$ But it was precisely this success that reduced the life chances of the 1965 and 1971 Hague Conventions. The European Member States of the Conference, focused on litigation in Europe, showed little interest in the Hague instruments, although these could have provided a bridge to non-European countries. As a result, these other countries also lacked interest, especially the US, which had a liberal system for recognition and enforcement of foreign judgments but was keen to obtain more easy recognition and enforcement of US judgments in Europe.

\subsubsection{Other reasons why the 1971 Recognition and Enforcement Convention failed}

11. There were two further reasons why the 1971 Hague Convention never got off: its alleged discriminatory effect, and the bilateralisation requirement. The 1968 Brussels Convention had been severely criticized by the American Prof. Nadelmann for discriminating against defendants based outside Europe. The Convention (in its Art. 4, now Art.6 of Brussels I recast) not only provides that persons domiciled in a Member State may, whatever their nationality, avail themselves of the exorbitant bases of jurisdiction in force in that Member States as against any defendant not domiciled in the EU but also makes these heads of jurisdiction available to any person domiciled in an EU Member State, and amplifies their effect by ensuring the free circulation of the resulting judgment in the other EU Member States. This criticism prompted the US delegation, supported by the United Kingdom, to propose, as an additional instrument to the 1971 Convention, the 1971 Protocol (supra 8.), in order to neutralize these effects. But the Protocol complicated the operation of the Convention.

of the European Parliament and of the Council of 12 December 2012 on jurisdiction and the recognition and enforcement of judgments in civil and commercial matters, OJ L 351, 20.12.2012.

13 Convention on jurisdiction and the enforcement of judgments in civil and commercial matters (1988), OJ L 319, 25.11.1988.

14 Convention on jurisdiction and the recognition and enforcement of judgments in civil and commercial matters, OJ L 339, 21.12.2007. 
12. Interestingly, the discrimination argument was heard less as negotiations in the Hague progressed, probably because it became more widely accepted that the EU should be seen as one unity in respect of the circulation of judgments. Contrary to the Protocol to the 1971 Convention, the 2018 Draft does not contain a list of prohibited indirect grounds of jurisdiction, but only of exclusive indirect grounds (Art.6). Yet, one could imagine that the discrimination argument might revive with Brexit, unless the UK were to remain bound by the Lugano Convention in either its 1988 or 2007 versions. If not, exorbitant bases of jurisdiction in EU Member States will revive against defendants domiciled in the UK! ${ }^{15}$

13. The second issue - bilateralisation - has not disappeared. As noted, the 1971 Convention was to work only between Contracting States that had concluded a bilateral treaty to that effect, as a negotiated expression of mutual trust. This forces Contracting States to decide, in respect of any other Contracting State, whether or not to accept that State as a partner for purposes of recognition and enforcement. That does not facilitate ratification. At this point, the question whether the future Hague Convention on Recognition and Enforcement should be based on a system of bilateralisation is still open.

\subsection{The 1999 Preliminary Draft Convention and the 2001 Interim Text}

\subsubsection{Mixed convention, traité simple, traité double}

14. In May 1992, the legal adviser of the US State Department, in a letter to my predecessor Georges Droz, proposed that the Conference "take up the negotiations on a multilateral convention on the recognition and enforcement of judgments". ${ }^{16}$ Attached to the letter was a report by Prof von Mehren, setting out his idea of the "mixed" convention, which, as we have seen, also included proposals relating to direct adjudicatory jurisdiction. The US had initially envisaged bilateral negotiations with European States only, but when the Permanent Bureau pointed out the benefits of a multilateral instrument applying at the global level, and given the experience of the Hague Conference with multilateral treaty-making, the US chose the Hague Conference as the negotiating forum.

15. However, we felt that the 1971 Hague Convention could not simply be ignored. So we suggested that the prudent course would be to proceed, just as the Brussels Convention had developed, by starting negotiations on a single Convention, a traité simple, including perhaps indirectly prohibited grounds of jurisdiction,

15 For a discussion about a possible "discriminatory" effect of the current Draft, see infra fn. 33 .

16 For the history of the 2001 Interim text and the 1999 Preliminary Draft Convention, see Pocar, Honorati, 2005: 3-370. 
and then look whether the further step of a double Convention, traité double, was possible (Permanent Bureau, 1995: 231-293). However, the politics of the 1990's dictated a different course.

\subsubsection{The US v. the $E U$}

16. In fact, the dynamics of the negotiations were very much determined by the transatlantic dimension, with very different and, as it turned out, incompatible strategic objectives on each side. On the one hand, the US was interested in securing recognition and enforcement of its judgments in Europe, and non-discrimination for its US-based companies and persons regarding direct grounds of jurisdiction. But since the US pursued a liberal policy in respect of recognition and enforcement of foreign judgments, ${ }^{17}$ it had little to offer in exchange. On the other hand, Europe was primarily interested in seeing the US reduce the reach of jurisdiction of its courts over Europe-based companies and persons. This was, in the European strategy, the price the US should pay to obtain easier access for its judgments in Europe.

17. So, the negotiations in the period 1996-2001 were strongly focused on jurisdictional issues. The EU pushed towards a full double convention, which the US resisted. Tension mounted further with the 1997 Amsterdam treaty, which entered into force in 1999 and gave the EU legislative powers in the field of private international law. This led to the perception that the EU States parties acted as a block. A Preliminary Draft Convention was adopted in 1999, generally welcomed by European States but not by the US and some other States. By 2001, when the "Interim Text" full of disputed bracketed language, saw the light, it was clear that a comprehensive Convention dealing with both jurisdiction and recognition and enforcement was beyond our reach, and that the project had to be scaled down.

18. Nevertheless, the work invested in the project was not lost. Various ideas and provisions found their way into the COCC, as well as into the 2018 Draft. Moreover, the 1999 Nygh-Pocar Report on the Preliminary Draft Convention (Nygh, Pocar, 2000: 19-128) has been an invaluable reference tool not only for the Hartley-Dogauchi Explanatory Report on the $\mathrm{COCC}^{18}$ but also for the GarcimartínSaumier Report on the current draft Convention.

17 Recognition and enforcement in the US are not covered by federal statute, but mainly by two Uniform Acts, the 1962 Uniform Foreign Money-Judgements Recognition Act and the 2005 Uniform Foreign-Country Money Judgments Recognition Act. The liberal attitude towards recognition and enforcement which they reflect is followed, in those states of the US that have not adopted these two statutes and for judgments not covered by them, by common law principles based on comity.

18 Hartley, Dogauchi, 2005: 860-863. 


\subsubsection{Six major challenges}

19. Six major issues, in particular, prevented the conclusion of a comprehensive global traité double in 2001. Four of these were related to direct grounds of jurisdiction: (i) activity-based jurisdiction, (ii) the internet, (iii) consumer and employment contracts, and (iv) intellectual property (IP). The other two were (v) bilateralisation, and (vi) the relationship with the Brussels (and Lugano) regime. ${ }^{19}$ These issues had to be, and were, resolved in the context of the COCC. ${ }^{20}$ They will have to be resolved for the future Hague Convention.

\subsection{The 2005 Choice of Court Convention}

\subsubsection{How the COCC deals with these challenges}

20. Activity-based jurisdiction (major issue (i)) and the internet (ii) present challenges when it comes to determining the proper determination of the competent court in the absence of a designation by the parties. However, these issues disappear, or are at least very much reduced, where the parties agree themselves on the competent court, the situation contemplated by the COCC. Regarding consumer and employment contracts (iii), they are excluded from the scope of the COCC. The Convention also found a way to deal with IP issues (iv): it excludes issues of validity of patents and trademarks, the idea being that they should not be the object of contractual designation, but be litigated in the place where the IP rights were registered. But since that problem does not arise with unregistered rights such as copyright, these are included. On the other hand, agreements on the infringement of patents and trademarks are excluded again, except where they are part of a dispute on a licensing contract. The exclusions do not apply to proceedings if the excluded matter arises merely as a preliminary issue.

21. In the context of the COCC, limited to situations where the parties agree on the exclusive court, there was no need to provide for a bilateralisation mechanism (v). Importantly, the COCC found a solution for its relationship with the Brussels and Lugano regimes ${ }^{21}$ (vi), thus providing inspiration for the future Convention. ${ }^{22}$

19 Permanent Bureau, Some Reflections on the present state of negotiations on the Judgments Project in the context of the future work program of the Conference, Prel. Doc. No 16 of February 2002, Retrieved 01, February 2019, from https://assets.hcch.net/docs/fc32c43e-22ac-4cb18f79-67688d66b282.pdf

20 See, especially, van Loon, 2016: 46-51; van Loon, 2016: 11-29; Brand, 2016: 31-43; Stanivuković, 2016: 45-68; Musseva, 2016: 69-91; Alihodžić, 2016: 93-113; Süral, 2016: 115-132.

21 Art.26 (6) respectively 26 (2) and (3) of the COCC.

22 Art. 24 (4) and (2) and (3). For a critical discussion of Art. 24, however, see Noodt Tequila, Abou-Nigm, 2017/2018: 464-468. 


\subsubsection{Interaction COCC and Brussels I recast}

22. The COCC has had a substantial impact on the revised provisions on prorogation of jurisdiction (Art. 25) and lis pendens (Art. 31) of Brussels I recast. Conversely, this has facilitated the early approval of the COCC by the EU ${ }^{23}$. As we shall see, the COCC has also been a model for the 2018 Draft in many respects, including its scope and grounds for refusal of recognition and enforcement. But there are also departures from that model.

\section{Challenges for the future Convention}

\subsection{Changed Dynamics}

23. If one could say that at the time of the 2001 Interim Text, the EU-US dynamics prevailed, nowadays the negotiations in the Hague have changed and have acquired a more global character. China and other (formerly) "emerging" States have become more actively involved, and the treaty to be adopted in 2019 is bound to reflect more global interests. It has always been our hope at the Permanent Bureau that a judgments convention would serve the whole world, and it had been a major argument when we suggested the Hague Conference as the appropriate forum for the topic (supra 14).

24. In some respects, it has become more challenging to reach global agreement (Bonomi, 2015/2016: 1-31). ${ }^{24}$ A noticeable example here is IP (major issue (iv), supra 19.). Whereas the COCC found a solution for the inclusion of some IP-related issues in the treaty, in the course of the negotiations on the $2018 \mathrm{draft}$, China, the EU, the US, and others, each had their own views on whether IP should be included and, if so, which aspects. The 2018 Draft reflects this lack of common understanding.

25. On the other hand, the fact that the current work is limited to the recognition and enforcement of judgments, and does not address original jurisdiction of the courts, should make it easier to reach a consensus. For the purpose of such a convention, a foreign judgment needs to pass the test whether the court giving the judgment had a sufficient link with the case as defined, in general terms, by the Convention, in order to determine whether that judgment qualifies for

23 In addition to the EU (27 States), Denmark, Mexico, Montenegro and Singapore are Parties to the COCC. With a view to ensuring the continued application of the Convention, in the event of and subject to a "no deal" in the Brexit negotiations, the UK signed and ratified the Convention on 28 December 2018, entry into force on 1 April 2019. China and the US have signed but not yet ratified the Convention.

24 This article discusses an earlier draft text, but is still relevant. See also Teitz, 2019. 
recognition and enforcement in the State addressed. But States remain free to determine on which grounds their courts may, or may not, assume jurisdiction. So, contrary to the COCC which excludes consumer and employment contracts (major issue (iii), supra 19), judgments in such matters are included in the 2018 Draft.

26. Nevertheless, the difference in approach between the US and other States to adjudicatory jurisdiction, although reduced by recent US Supreme Court decisions, remains an important issue even at the stage of recognition and enforcement of judgments. As a result, major issues in activity-based jurisdiction (i), and the Internet (ii), referred to above, pose challenges for the current negotiations as well.

\subsection{Judicial jurisdiction: the US compared with other States}

27. In the US, judicial jurisdiction is a constitutional matter ${ }^{25}$ and, in that respect, its position is rather unique. ${ }^{26}$ Whatever statutes in the US say about the reach of the jurisdiction of the courts, the courts must apply constitutional principles of due process to check that the limitations of due process are not exceeded. According to International Shoe v. Washington, ${ }^{27}$ the defendant must have "minimum contacts" with the forum state such that the maintenance of the suit does not "offend traditional notions of fair play and substantial justice". This leads to a focus on the relationship between the defendant and the forum, whereas in Europe and other States it is the relationship between the subject matter of the litigation (or claim) and the forum that is the relevant touchstone.

28. At the same time, in the US, the defendant is brought to court for purposes of adjudicatory jurisdiction not only where he/she is domiciled ${ }^{28}$ - the dominant approach of the Brussels/Lugano system - but also when he/she is active in a State or directs activity at that State - a criterion which in Brussels I recast only appears in Art. 4 (1) (c). If the defendant is not domiciled in a State, but is doing business there in a continuous and systematic manner, he/she may be brought to court in that country, even if the claim arises out of the activity of the defendant elsewhere, not in that State: general jurisdiction.

25 In Pennoyer v. Neff, (95 U.S. 714 (1878)) the US Supreme Court decided that when it comes to adjudicatory jurisdiction defendants are protected under the Fifth and Fourteenth amendments of the US Constitution

26 For a recent overview see Silberman, 2019.

27 International Shoe v. Washington, 326 U.S. 310 (1945).

28 Or deemed to be domiciled, see Arts. 11 (2), 17 (2), and 20 (2) of the Brussels Regulation (Recast). 
29. Recently, and in part as a result of the criticisms expressed during the negotiations on the judgments project in The Hague of the overly broad assertion of jurisdiction to which this may lead, the US Supreme Court ${ }^{29}$ has narrowed the standard for general jurisdiction. A corporation's link with the forum must be so continuous and systematic as to render the defendant essentially "at home" in the forum State, which comes close to the place of incorporation and principal place of business known in the Brussels/Lugano system.

30. If the defendant, although not present in the forum country, is active there, or directs activity at that country but not in such a continuous and systematic manner as to render the defendant "essentially at home" in that country, then he/she may still be subject to the jurisdiction of that court, provided the claim "arises out of that activity": specific jurisdiction. This, however, requires "purposeful availment" by the defendant of "the benefits and protections of [the forum State's] laws"30. Again, recent case-law of the Supreme Court has limited the reach of the "arising out/purposeful availment" requirement ${ }^{31}$.

31. So, in respect of contracts, the court-dispute connection based on the place of performance of the contract, as defined by Art. 7 (1) of Brussels I recast, is in the US view too narrow (on the one hand) because it does not provide for jurisdiction where the defendant, without being active in that country, directed its activity at that country. But, on the other hand, it is too broad because it may lead to jurisdiction of a court in a country in which the defendant neither was active nor at which it directed activities.

32. In respect of torts (Art 7 (2) Brussels I recast), the EU and US approaches do not conflict so far as the court-claim connection is based on the place where the act or omission causing the injury occurs. But where the court-claim connection is based simply on the place where the injury arose, and not on "purposeful conduct" of the defendant, the US has a problem. In the US view, this is only acceptable if the defendant's activity is in one way or another directed at the country where the injury took place. In Walden v. Fiore ${ }^{32}$, the US Supreme Court recently ruled that mere injury suffered by a forum resident is not a sufficient

29 First in Goodyear Dunlop Tires v. Brown, 131 S. Ct. 2846 (2011), then in Daimler AG v. Bauman, 134 S.Ct. 746 (2014). In Daimler (p.23), the Supreme Court refers to the Solicitor General's brief, according to which "foreign governments 'objections to some domestic courts' expansive views of general jurisdiction have in the past impeded negotiations of international agreements on the reciprocal recognition and enforcement of judgments" an indirect reference to the Hague negotiations on a "mixed "convention.

30 Justice O'Çonnor, in Asahi Metal Industry Co. v. Superior Court, 107 S.Ct.1026 (1987).

31 See McIntyre Machinery, Ltd. v. Nicastro, 131 S. Ct. 2780 (2011); Bristol-Myers Squibb Co. v. Superior Court of California, 137 S. Ct. 1773 (2017).

32 Walden v. Fiore, 134 S. Ct. 1115 (2014). 
connection between the defendant and the forum. Internet jurisdiction, both in defamation and in other cases, including concerning trademark infringement, raises special questions relating to what "purposeful availment" implies.

33. Not surprisingly, then, the forum actoris, provided for by the Brussels/Lugano regime, enabling weak parties such as insured persons, consumer and employees to sue a defendant who is domiciled abroad in the court of their own domicile, only based on the fact of their being domiciled there, is not acceptable for the US.

\section{Impact on the 2018 Draft Convention}

34. The difference in approach between the US, focused on the defendant-forum relationship, and that of the Brussels/Lugano regime and other States, focused on the dispute (claim)-forum relationship, is reflected in the 2018 Draft, in particular its Article 5, which deals with indirect bases for recognition and enforcement. ${ }^{33}$ But the 2018 Draft also echoes other, economic and cultural differences, including in relation to intellectual property, defamation and privacy.

\subsection{Contracts}

35. Article 5 (1) (g), in its first limb, focusing on the place of performance, reflects the court-dispute approach. Therefore, it does not cover judgments given by a court of a country where a significant amount of (preparatory) work was done under the contract but not such that it qualified as "the place of performance". On the other hand, the second limb excludes recognition and enforcement of judgments based on the test of the first limb where "the defendant's activities did not constitute a purposeful and substantial connection to that State". This meets the US defendant-forum requirement, but implies a limitation of the Brussels/Lugano approach, and reduces predictability.

33 For criticism of the approach followed by art. 5, see Brand, 2019. He argues that "[in contrast to] just about every trade treaty [emphasis added $H v L$ ]...the Draft text does not include a rule of non-discrimination. Rather, through the choice of a specific set of rules of indirect jurisdiction in Article 5(1), it allows those states which discriminate in the process of judgments recognition to continue to do so". However, while the Draft certainly seeks to facilitate international trade by enhancing the free flow of judgments, that does not make it a trade treaty subject to the rule of non-discrimination regarding foreign products and services. It is true that the Draft does not oblige the requested State to apply a recognition and enforcement test based on whether or not the original court had based its judgment on a ground of direct jurisdiction available in the requested State, as Prof. Brand would have preferred (and for which a precedent may be found in Art. 20(3) of the 2007 Hague Child Support Convention). But, for the purpose of the test of Article 5, incoming judgments from all Contracting States are to be treated uniformly, without discrimination. 


\subsection{Torts}

36. Article 5 (1) (j) on non-contractual obligations, including torts, is narrowly drafted in two respects. First, in terms of the types of damage with which the judgment is concerned: "death, physical injury, damage to or loss of tangible property", thus excluding immaterial damage among other matters. Second, by excluding judgments rendered by the courts of the State where the injury arose, if that was not also the State where the act or omission took place. This is a more limited approach than that of the Court of Justice of the European Union (CJEU) interpreting the Brussels Convention, ${ }^{34}$ according to which both the court of the place where the damage is caused and where the injury arose have jurisdiction. It is even narrower than the 2001 Interim text, which, analogous to the provision on contractual obligations (supra 35.), ${ }^{35}$ did include this basis of jurisdiction subject to a foreseeability test. ${ }^{36}$ It is hoped - also in the light of the 2030 UN Agenda for Sustainable Development which highlights the current "immense challenges to sustainable development" 37 - that the final text will make room for recognition and enforcement of judgments emanating from the court of the place where the injury arose if the defendant could reasonably foresee that its conduct would give rise to the harm in that State (van Loon, 2018: 298-318).

\subsection{Internet}

37. Courts in the US, the EU, and Canada continue to wrestle with issues of jurisdiction concerning defamation through the Internet, which may cause damage in multiple States. In Keeton v. Hustler Magazine, ${ }^{38}$ in the context of print distribution, the US Supreme Court permitted a defamation claim for the totality of the damage, even in a forum where minimal damage occurred. By contrast, the CJEU, in Shevill v. Press Alliance, ${ }^{39}$, also a print defamation case, ruled that a

\section{CJEU, C-21-76, Bier v. Mines de Potasse (1976).}

35 Art. 10 of the 2001 Interim Text read as follows: A plaintiff may bring an action in tort or delict in the courts of the State a) in which the act of omission that caused the injury occurred or b) in which the injury arose, unless the defendant establishes that the person claimed to be responsible could not reasonably have foreseen that the act or omission could result in an injury of the same nature in that State.

36 This probably reflects uncertainty regarding the US Supreme Court's position in respect of the requirements for the exercise of specific jurisdiction over a non-resident defendant, following its recent decision in Bristol-Myer Squibb v. Superior Court (supra, fn. 32)

37 UN, Transforming our world: the 2030 Agenda for Sustainable Development, Retrieved 01 February 2019, from https://sustainabledevelopment.un.org/post2015/ transformingourworld, par. 14.

38 Keeton v. Hustler Magazine, 465 U.S. 770 (1984).

39 CJEU 7 March 1995, C-68/93, ECLI:EU:C:1995:61 
plaintiff may sue only for the damage suffered in the State of distribution (" $m o$ saic" approach), and can recover full damages or injunctive relief only suing in the place where the publisher is established. However, in eDate Advertising and Others ${ }^{40}$ and Bolagsupplysningen $O U$ v. Svensk Handel $A B,{ }^{41}$ both Internet cases, the CJEU found that the plaintiff may, in addition, bring a suit for full damages and injunctive relief in the courts of the Member State where the plaintiff has the "centre of his interests". A recent Canadian Supreme Court decision on Internet defamation is conspicuous by a sharp division of the justices regarding the application of forum non conveniens..$^{42}$ In view of these differences, and more fundamental cultural variances on the balance between freedom of speech and protection of personal reputation, it comes as no surprise that the 2018 Draft excludes defamation altogether, Art. 2 (1) (k).

\subsection{Intellectual Property}

38. Other types of cases may also involve the Internet, for example infringement of trademarks or commercial contracts. Art. 5 (3) under (a) and (b) has bracketed language to deal with a judgment given by, for example, a court in the State of registration of a trademark against a defendant who offers cloud based services from an interactive website attracting customers from around the world for infringement of that trademark, without having acted in or targeted activities at that State.

39. But Art. 5 (3) itself appears in brackets, as do Arts. 6 (a), 7 (1)(g), 8 (3), and 11. Moreover, Art. 2 (1) (m) potentially excludes IP altogether. A complete exclusion of IP would be a step back in comparison with the COCC, so hopefully it will be possible to avoid such a far-reaching decision.

\subsection{Consumers and employees}

40. Contrary to the COCC, the 2018 Draft includes judgments on consumer and employee contracts. Where the consumer or employee seeks recognition and enforcement of a judgment in their favour, other rules apply. However, the trader/ employer will only obtain recognition and enforcement against a consumer or employee, where they have addressed to the court their express consent to its jurisdiction and the Draft excludes in that case judgments given by the court of performance (Art. 5 (2)). Nor does it provide for recognition and enforcement of judgments given by courts of the consumers' or employees' domicile, or the

40 CJEU 25 October 2011, C-509/09,ECLI:EU:C:2011:685

41 CJEU 17 October 2017, ECLI:EU:C:2017:766

42 Haaretz.com v. Goldhar, 2018 S.C.C. 28. 
place where the employee habitually carries out his/her work (in contrast to Arts. 17-23 Brussels I recast).

\section{Other features of the 2018 Draft Convention}

\subsection{Exclusions/Inclusions}

41. The exclusions from scope of the 2018 Draft largely coincide with those of the COCC. But the 2018 Draft includes judgments given in anti-trust (competition) matters - still in brackets, as a sensitive matter - and on claims for personal injury, damage to tangible property, and rights in rem (Permanent Bureau, 2018). As in the COCC, where an excluded matter arises merely as a preliminary issue in the proceedings, it does not trigger the exclusion of the judgment: Art. 2 (2). But the ruling on that preliminary matter itself shall not be recognised and enforced under the Convention (but may still be under national law), and insofar as the judgment was based on a ruling on that matter, it may be refused (Art. 8). Contrary to Art. 10 (4) COCC, a reference to Art. 19 is missing however. Also contrary to the COCC (Art. 17), the 2018 Draft does not contain a provision for contracts of (re-)insurance relating to a matter to which the Convention does not apply.

42. Similar to the COCC, the 2018 Draft provides that "proceedings are not excluded from the scope of the Convention by the mere fact that a State, including a government, a governmental agency or any other person acting for a State, is a party thereto" (Art. 2 (4)). However, Art. 20, in bracketed language, permits Contracting States to reverse this rule, by declaring, with reciprocal effect, that it will not recognise or enforce such a judgment when that State, or an agency or person acting on its behalf, itself is involved except where it concerns an enterprise owned by a State.

\subsection{Exclusive bases for recognition and enforcement. Recognition and Enforcement under national law}

43. Art. 6 obliges courts to refuse recognition and enforcement of judgments that do not respect the requirements of Art. 6 (a)(supra 39),(b) and (c). As noted, the Draft Convention does not include a list of prohibited bases for recognition and enforcement, but indirectly these provisions have a similar effect regarding judgments not based on the exclusive bases of Art. 6. This is an exception to Art.16, which makes it clear that the Convention is generally non-exclusive, leaving Contracting States free to recognise and enforce judgments on any basis not foreseen, or on any matter excluded, by the Convention. 


\subsection{Refusal of recognition or enforcement and procedural matters}

44. Arts. 7 (grounds of refusal), 8 (preliminary questions) (supra 41.), 9 (severability), 10 (punitive damages), 12 (judicial settlements), 13 (documents), and 14 (1) (procedure) correspond largely with, or are even identical to, Articles 9, $10,15,11-14$ of the COCC.

45. Art 7 (1) (b), permitting refusal of recognition and enforcement if the judgment is obtained "by fraud" contrasts with the corresponding provision of the COCC, limited to fraud "in connection with a matter of procedure". As with the added language in par. (c) ("...and situations involving infringements of security or sovereignty of that State"), the risk is that this may invite a review of the merits of the judgment, contrary to the provision of Art. 4 (2) which prohibits such review. Art. 7 (1) (d) extends the idea underlying the COCC that court designations by the parties must be respected, to non-exclusive choice of court agreements and agreements in trust instruments.

46. The 2018 Draft contains several interesting novelties. One novelty is the provision of Art. 4 (4), which gives the requested court a certain flexibility in dealing with judgments that are subject to review in the State of origin. Contrast this with many national recognition regimes requiring that the judgment must be final. Another novelty is the exclusion by Art. 14(2) of the application of the forum non conveniens test at the stage of recognition and enforcement: the requested court may not refuse the recognition or enforcement of a judgment on the ground that the requesting party had better seek such recognition or enforcement in another State ${ }^{43}$. Another helpful provision is Art. 15 on security for costs, inspired by Articles 14 and 15 of the 1980 Hague Convention on Access to Justice.

\subsection{Judgments given by a common court}

47. Another novelty is the provision, in bracketed language, dealing with judgments rendered by "common courts" (Art 4 [(5)], [(5) and (6)]). These are courts established by two or more States, such as the Common Court of Justice and Arbitration of the Organization for the Harmonization of Business Law (CCJA); the Caribbean Court of Justice (CCJ); the Judicial Committee of the Privy Council (JCPC); or the future Unified Patent Court. But since the EU counts as a "Contracting State", as it may itself become a Party to the future Convention, the CJEU is not to be considered as a common court.

43 Note that the Convention, being a traité simple, does not and cannot exclude the application of the forum non convenience by the court originally addressed. 
48. The 2018 Draft seeks to establish the conditions under which a judgment rendered by a common court "shall be deemed to be a judgment given by a court of a Contracting State". First, a declaration of a Contracting State identifying such a court is required. Second, the draft deals with the "free rider" problem, i.e., it seeks to prevent recognition or enforcement of a judgment rendered by a common court in situations where one or more of the States on whose behalf the common court exercises jurisdiction is not a Party to the Convention. Otherwise, a State could benefit from the Convention without binding itself to it $^{44}$. Finally, the Declaration has effect in the relation to other Contracting States only if they have not opted out from (Art. [6], first alternative), or into it (Art. [6], second alternative).

\section{Conclusion}

49. There is a certain irony in the fact that, when later this year the Convention on the Recognition and Enforcement of Judgments will see the light, the work that started in the 1960's with the 1965 Choice of Court and the 1971 Recognition and Enforcement Conventions will have come full circle: the Hague Conference will, once again, after having crafted an instrument on choice of court, adopt a Recognition and Enforcement Convention! Yet, the image of an upward spiral will hopefully do better justice to the outcome. If one compares the 1965 and 2005 Choice of Court Conventions, it is only fair to note that the former went only half way, in particular insofar as it did not unify the rules of recognition and enforcement of judgments but left these to national law, and it never came into force, whereas the 2005 Convention now binds 32 States, has been signed by the US and China, and is likely to attract more Parties in the future.

50. The reasons for the failure of the 1971 Convention have been set out supra 10.-13. The structure of the new Convention will hopefully be less complicated than that of its predecessor. A bilateralisation requirement should be avoided, or at least drafted in a way that makes the application of the Convention not unduly difficult.

Contrary to the situation forty years ago, there is no competing (European or international) instrument available. On the contrary, through its membership of the Hague Conference (since 2007), the EU has acknowledged the importance of this organisation as a forum for negotiating global instruments. For the EU, the Judgments Project is now a priority project of the gradual construction of an external EU policy on judicial cooperation in civil and commercial matters.

44 Subparagraph (a) excludes such situations where the judgment is based on consent only of the parties. Subparagraph (b) deals with all other situations, in so far as a clear link can be established between the judgment and a Contracting State. 
From a global perspective, the Convention will fulfill a long-felt need for a multilateral framework for the recognition and enforcement of judgments. The Convention will, as a whole, contribute to the aforementioned 2030 UN Agenda for Sustainable Development which encourages the international community to "promote the rule of law at the national and international levels and ensure equal access to justice for all" (Sustainable Development Goal 16.3). ${ }^{45}$ In terms of its scope, if (for example) IP and or anti-trust matters were excluded, it may end up as a rather modest instrument, but that may be inevitable to attract worldwide participation. In the future, its substantive reach might also be broadened, through additional protocols. ${ }^{46}$

It will be very important to focus the energy of the Conference on the promotion and follow up on the implementation and application of the future Convention. This will require considerable efforts, from which work on a possible "traité double" (supra 2.) should not detract. After so many years of intense study, dialogue and negotiations, the 2019 Convention on the Recognition and Enforcement of Judgments in Civil or Commercial Matters has the potential of meeting the need for a truly global common framework for the circulation of judgments in our emerging world society.

\section{Literature/References}

Alihodžić, J. (2016). The Hague Convention 2005 and Bosnia and Herzegovina. Anali Pravnog fakulteta u Zenici. 18(9). 93-113.

Asahi Metal Industry Co. v. Superior Court, 107 S.Ct.1026 (1987).

Bonomi, A. (2015/2016). Courage or caution? A critical overview of the Hague Preliminary Draft on Judgments. Yearbook of Private International Law, Volume 17 (2015/2016). 1-31.

Brand, R. (2016). The 2005 Hague Choice of Court Convention in the United States. Anali Pravnog fakulteta u Zenici. 18(9). 31-43.

Brand, R. (2019). The Circulation of Judgments under the Draft Hague Judgments Convention. Retrieved 01, February 2019, from https://papers.ssrn.com/sol3/ papers.cfm?abstract_id=3334647

45 See, both on the EU and the global perspective on the future Convention, Pertegás, 2018: 67-82.

46 Cf. Art. 22 of the 2018 Draft: "The Secretary General of the Hague Conference on Private International Law shall at regular intervals make arrangements for (a) review of the operation of this Convention, including any declarations; and (b) consideration of whether any amendments to this Convention are desirable. 
Bristol-Myers Squibb Co. v. Superior Court of California, 137 S. Ct. 1773 (2017).

Brussels Convention on jurisdiction and the enforcement of judgments in civil and commercial matters (1968), OJ L 299, 31.12.1972.

CJEU, C-21-76,Bierv. Mines de Potasse, CJEU 30 November 1976. ECLI:EU:C:1976:166.

CJEU, Bolagsupplysningen OU v. Svensk Handel AB, 17 October 2017, ECLI:EU:C:2017:766.

CJEU,eDateAdvertising andOthers, 25 October 2011,C-509/09, ECLI:EU:C:2011:685.

CJEU, Shevill v. Press Aliance, 7 March 1995, C-68/93, ECLI:EU:C:1995:61.

Convention of 1 February 1971 on the Recognition and Enforcement of Foreign Judgments in Civil and Commercial Matters.

Convention of 15 April 1958 concerning the recognition and enforcement of decisions relating to maintenance obligations towards children.

Convention of 15 April 1958 on the jurisdiction of the selected forum in the case of international sales of goods.

Convention of 25 November 1965 on the Choice of Court.

Convention of 30 June 2005 on Choice of Court Agreements.

Convention of 23 November 2007 on the International Recovery of Child Support and Other Forms of Family Maintenance.

Convention on jurisdiction and the enforcement of judgments in civil and commercial matters (1988), OJ L 319, 25.11.1988.

Convention on jurisdiction and the recognition and enforcement of judgments in civil and commercial matters, OJ L 339, 21.12.2007.

Council on General Affairs and Policy of the Hague Conference on Private International Law, Conclusions and Recommendations, March 2018, Retrieved 1 February 2019, from https://www.hcch.net/en/governance/council-on-general-affairs> Archive> Meeting 2018.

Council Regulation (EC) No 44/2001 of 22 December 2000 on jurisdiction and the recognition and enforcement of judgments in civil and commercial matters, OJ L 12, 16.1.2001.

Daimler AG v. Bauman, 134 S.Ct. 746 (2014).

Draft Convention on the Recognition and Enforcement of Foreign Judgments in Civil or Commercial Matters, Retrieved 1, February 2019, from https://assets. hcch.net/docs/9faf15e1-9c36-4e57-8d56-12a7d895faac.pdf 
Droz, G. (1969). Explanatory Report on the Supplementary Protocol of 1 February 1971 to the Hague Convention on the Recognition and Enforcement of Foreign Judgments in Civil and Commercial Matters. In Acts and Documents of the Extraordinary Session (1966, pp.498-504). The Hague: HCCH Publications.

Fragistas, Ch. (1969). Explanatory Report on the 1971 Hague Judgments Convention. In Acts and Documents of the Extraordinary Session (1966, pp. 360-388). The Hague: HCCH Publications.

Goodyear Dunlop Tires v. Brown, 131 S. Ct. 2846 (2011).

Haaretz.com v. Goldhar, 2018, S.C.C. 28.

Hartley, T., Dogauchi, M. (2005). Explanatory Report of the Convention of 30 June 2005 on Choice of Court Agreements. Retrieved 01 February 2019 from https:// assets.hcch.net/upload/expl37final.pdf

International Shoe v. Washington, 326 U.S. 310 (1945).

Keeton v. Hustler Magazine, 465 U.S. 770 (1984).

McIntyre Machinery, Ltd. v. Nicastro, 131 S. Ct. 2780 (2011).

Musseva, B. (2016). Opposability of Choice-of-Court Agreements against Third Parties under the Hague Choice-of-Court Convention and Brussels Ibis Regulation. Anali Pravnog fakulteta u Zenici. 18(9). 69-91.

Noodt Tequila, M., Ruiz Abou-Nigm, V. (2017/2018). The Draft Judgments Convention and its Relationship with other International Instruments. Yearbook of Private International Law, 19(2017/2018). 449-474.

Nygh, P., Pocar, F. (2000). Report of the Special Commission of the Preliminary Draft Convention on Jurisdiction and Foreign Judgments in Civil and Commercial Matters. Retrieved 01 February 2019 from https://assets.hcch.net/docs/638883f3-0c0a46c6-b646-7a099d9bd95e.pdf

Pennoyer v. Neff, (95 U.S. 714 (1878)) of the US Supreme Court.

Permanent Bureau (2018). The possible exclusion of anti-trust matters from the Convention as reflected in Article 2 (1) (p) of the 2018 draft Convention. Retrieved 01 February 2019 from https://assets.hcch.net/docs/dcd7c92a-d3fd-46a5-bae5627ff1636003.pdf

Permanent Bureau (2019). Some Reflections on the present state of negotiations on the Judgments Project in the context of the future work program of the Conference, Prel. Doc. No 16 of February 2002, Retrieved 01 February 2019 from https:// assets.hcch.net/docs/fc32c43e-22ac-4cb1-8f79-67688d66b282.pdf 
Permanent Bureau of the Hague Conference on Private International Law (1995). Some reflections of the Permanent Bureau on a general convention on enforcement of judgments (Prel. Doc. No. 17 of May 1992). In the Proceedings of the Seventeenth Session, Tome I, Miscellaneous Matters (pp. 231-293). The Hague: HCCH Publications.

Permanent Bureau of the Hague Conference on Private International Law and the Co-reporters (2001), Summary of the Outcome of the Discussion in Commission II of the First Part of the Diplomatic Conference 6-0 June 2001, Interim Text, Retrieved 01 February 2019 from https://assets.hcch.net/docs/e172ab52-e2de4e40-9051-11aee7c7be67.pdf

Pertegás, M. (2018). Brussels I Recast and the Hague Judgments Project. In: G. Van Calster \& Jura Falconis (eds.), European Private International Law at 50 (pp. 67-82). Antwerp: Intersentia.

Pocar, F., Honorati, C. (eds). The Hague Preliminary Draft Convention on Jurisdiction and Judgments, Proceedings of the Round Table held at Milan University on 15 November 2003. Milan: Wolters Kluwer Italia

Prel. Doc.No 1 of December 2018 - Judgments Convention: Revised Draft Explanatory Report, Retrieved 01 February 2019 from https://assets.hcch.net/ docs/7d2ae3f7-e8c6-4ef3-807c-15f112aa483d.pdf

Preliminary Draft Convention on Jurisdiction and Foreign Judgments in Civil and Commercial Matters, Retrieved 01 February 2019, from https://assets.hcch. net/docs/638883f3-0c0a-46c6-b646-7a099d9bd95e.pdf

Regulation (EU) No 1215/2012 of the European Parliament and of the Council of 12 December 2012 on jurisdiction and the recognition and enforcement of judgments in civil and commercial matters, OJ L 351, 20.12.2012.

Silberman, L. (2019). Judicial Jurisdiction and Forum Access - The Search for Predictable Rules. In: F. Ferrari \& D. Fernandez Arroyo (eds.), The Continuing Relevance of Private International Law and Its Challenges. Edward Elgar Publishing.

Stanivuković, M. (2016). Choice of Court Convention (HCCH) and Arbitration. Anali Pravnog fakulteta u Zenici. 18(9). 45-68.

Supplementary Protocol of 1 February 1971 to the Hague Convention on the Recognition and Enforcement of Foreign Judgments in Civil and Commercial Matters.

Süral, B. C. (2016). Possible Impact of the Hague Convention on Choice of Court Agreements on Turkish Law. Anali Pravnog fakulteta u Zenici. 18(9). 115-132. 
Teitz, L.E. (2019). Another Hague Judgments Convention? Bucking the Past to Provide for the Future. 29 Duke Journal of Comparative \& International Law. 29(2019).

UN, Transforming our world: the 2030 Agenda for Sustainable Development, Retrieved 01 February 2019 from https://sustainabledevelopment.un.org/ post2015/transformingourworld, par. 14.

van Loon, H (2018). Principles and building blocks for a global legal framework for transnational civil litigation in environmental matters. Uniform Law Review, 23 (2018). 298-318.

van Loon, H. (2016). The 2005 Hague Convention on Choice of Court Agreements - an Introduction. Anali Pravnog fakulteta u Zenici. 18(9). 11-29.

van Loon, H. (2016). The Global Horizon of Private international Law. Recueil des cours/Collection of Courses of the Hague Academy of International Law (vol. 380). The Hague: Brill | Nijhoff

von Mehren, A.T. (2002). Theory and Practice of Adjudicatory Authority in Private International Law: A Comparative Study of the Doctrine, Policies, and Practices of Common-Law and Civil-Law Systems, General Course. Recueil des Cours /Collected Courses of the Hague Academy of International Law (vol. 295). The Hague: Brill | Nijhoff

Walden v. Fiore, 134 S. Ct. 1115 (2014). 


\section{Hans van Loon,}

Бивши генерални секретар Хашке конференције о

међународном приватном праву (1996-2013),

Члан Института за међународно право

\section{КА ГЛОБАЛНОЈ ХАШКОЈ КОНВЕНЦИЈИ О ПРИЗНАҢУ И ИЗВРШЕЊУ ПРЕСУДА У ГРАЪАНСКИМ ИЛИ ТРГОВАЧКИМ СТВАРИМА}

\section{Резиме}

Дипломатска седнища Хашке конференције о међународном приватном праву посвећена усвајању Конвенције о признању и извршењу пресуда у грађанским или трговачким стварима одржаће се у периоду од 18. јуна до 2. јула 2019. године. Уовом раду дат је осврт на историју тог пројекта, који сеже до 1992. године, када су Сједињене Америчке Државе предложиле усвајање „мешовите конвенције“. С тим у вези, разматра се и динамика иницијалних преговора: разлози због којих преговори нису могли да изнедре конвенцију која би, осим признања и извршења пресуда, унификовала и основе директне међународне надлежности, већ су довели до отпочињањ а преговора о усвајању Конвенције о избору суда из 2005. године, чији је домашај ограничен на споразуме о избору (искључиво) надлежног суда и признање и извршење пресуда донетих на основу таквих споразума. Аутор такође разматра околности под којима је дошло до актуелних преговора који су довели до израде Нащрта Конвенције о признању и извршењу пресуда (маја 2018. године), чије је поље примене ограничено само на признање и извршење пресуда. Упркос наведеном ограничењу, разлике које постоје између САД-а и других држава по питању судске надлежности и даље имају важан утищај на признање пресуда у материји уговора, деликата, активности на интернету, интелектуалне својине, права потрошача и запослених. У раду се наводи и неколико других карактеристика Нащрта Конвенције из 2018, које једним делом почивају на Конвенцији о избору суда а другим делом представљају новине. Напослетку, аутор закључује да с́е будус́а конвенција, иако је поље њене примене можда мање амбициозно од онога што је испрва планирано, ипак испунити дугогодишња очекивања на глобалном плану.

Кључне речи: Нацрт Хашке конвенције о признавању и извршењу пресуда, Хашка конвенција о избору суда, Регулатива Брисел I (recast), динамика и изазови преговарачког процеса, основи директне и индиректне међународне надлежности, судска надлежност у САД и другим државама, уговори и деликти, интелектуална својина, разлози одбијања признања, билатерализација. 